\title{
The relationship between a sedentary lifestyle and human health in the light of the research of PONS-Healthy Kielce
}

\section{Zależności pomiędzy siedzącym stylem życia a zdrowiem człowieka w świetle badañ PONS-Zdrowe Kielce} \author{
Barbara Sosnowska-Pasiarska6 ${ }^{6}$, Stanisław Góźdźz,7 \\ 'Department of Rehabilitation, Holy Cross Cancer Centre, Kielce, Poland \\ Head of the Department: Anna Opuchlik, MD, PhD \\ 2Faculty of Medicine and Health Sciences, Jan Kochanowski University, Kielce, Poland \\ Head of the Faculty: Prof. Marianna Janion \\ ${ }^{3}$ Department of Epidemiology and Fight Against Cancer, Holy Cross Cancer Centre, Kielce, Poland \\ Head of the Department: Paweł Macek, MD, PhD \\ ${ }^{4}$ Faculty of Medical Sciences, School of Economics, Law and Medical Sciences, Kielce, Poland \\ Head of the Faculty: Grzegorz Gałuszka, MD, PhD \\ ${ }^{5}$ Research and Education Department, Holy Cross Cancer Centre, Kielce, Poland \\ Head of the Department: Halina Król, PhD \\ ${ }^{6}$ Department of Cardio-Oncology, Holy Cross Cancer Centre, Kielce, Poland \\ Head of the Department: Piotr Biskup, MD, PhD \\ ${ }^{7}$ Medical Oncology Clinic, Holy Cross Cancer Centre, Kielce, Poland \\ Head of the Clinic: Prof. Stanisław Góźdź
}

Małgorzata Biskup ${ }^{1,2}$, Paweł Macek ${ }^{3,4}$, Halina Król2,5, Małgorzata Terek-Derszniak ${ }^{1}$, Tomasz Skowronek ${ }^{1}$,

Key words: sedentary lifestyle, PONS-Healthy Kielce study, BMI, waist-hip ratio, waist circumference.

Słowa kluczowe: siedzący tryb życia, badania PONS-Zdrowe Kielce, BMI, wskaźnik WHR, wskaźnik WC.

\begin{abstract}
Aim of the research: The evaluation of the prevalence of sedentary life among inhabitants of the city of Kielce, considering gender, education, body mass index (BMI), and civilization diseases.

Material and methods: The analysis included data of 4,777 participants (mean age, 56.31) from the PONS-Healthy Kielce study. On the basis of a study questionnaire, the time spent in a sitting position was calculated. Additionally, the relationship between the amount of time spent sitting and gender, education, BMI, and the occurrence of civilization diseases was analyzed.

Results: Significant associations were reported between sedentary lifestyle and gender within a male population of the study. With the increase of participants educational level, more time was spent sitting on weekdays, whereas less time was spent on watching TV. With increasing level of education, the amount of total and average sitting time and total sitting time including travel time, increased. A significant relationship was noted between the amount of time spent sitting and BMI, and the occurrence of diseases and multiple morbidities.

Conclusions: Men more often than women prefer sedentary lifestyle. Inactive lifestyle is related to education, the occurrence of diseases, and to a number of co-existing diseases. Moreover, it disturbs normal body weight and has a negative effect on health. There is a need to implement prevention programs in order to combat obesity and promote physical activity among residents of Kielce.
\end{abstract}

\section{Streszczenie}

Cel pracy: Ocena rozpowszechnienia siedzącego trybu życia wśród mieszkańców miasta Kielce z uwzględnieniem płci, wykształcenia, wartości wskaźnika masy ciała (body mass index - BMI) oraz występowania chorób cywilizacyjnych.

Materiał i metody: Analizą objęto dane z badania PONS-Zdrowe Kielce pochodzące od 4777 uczestników (średnia wieku $56,31 \mathrm{roku}$ ). Na podstawie kwestionariusza ankiety określono czas spędzony w pozycji siedzącej. Analizie poddano również zależności między ilością czasu spędzanego w pozycji siedzącej a płcią, wykształceniem, wartością BMI oraz występowaniem chorób cywilizacyjnych.

Wyniki: Wykazano istotne związki pomiędzy siedzącym trybem życia a płcią, na niekorzyść mężczyzn. Wraz ze wzrostem poziomu wykształcenia badani spędzali więcej czasu, siedząc w dni robocze, mniej czasu spędzali natomiast, oglądając tele- 
wizję. Wraz ze wzrostem poziomu wykształcenia wzrastała ilość całkowitego i przeciętnego czasu siedzenia oraz całkowitego czasu siedzenia, łącznie z transportem. Wykazano wysoce istotne zależności pomiędzy ilością czasu spędzanego w pozycji siedzącej a wartościami BMI, występowaniem chorób oraz wielochorobowością.

Wnioski: Mężczyźni częściej niż kobiety preferują siedzący tryb życia, który wykazuje związki z wykształceniem, występowaniem chorób, liczbą współistniejących chorób, zaburza ponadto prawidłową masę ciała i pogarsza stan zdrowia. Istnieje konieczność wdrażania programów profilaktycznych zwalczających otyłość oraz propagujących aktywność fizyczną wśród mieszkańców Kielc.

\section{Introduction}

It is well known that regular physical activity results in numerous physiological, psychological, and social benefits, both immediate and long-term. The definition of physical activity is of particular importance to the threats that the modern world poses to a man. Civilization, with its obvious benefits and achievements, became the cause of the development of many diseases collectively referred to as civilization diseases, i.e. obesity, coronary heart disease, diabetes, and cancer. Throughout the twentieth century, the presence of physical labor decreased by around $80 \%$ for the benefit of mental work $[1,2]$.

Nowadays, an adult spends $50-60 \%$ of his time during the day sitting. The term "sedentary" comes from the Latin "sedere" (to sit), and can be operationally defined as any waking sitting or lying behavior with low-energy expenditure. This operational definition broadly fits the commonly cited technical definition of $<1.5$ metabolic equivalent units. Therefore, the term "sedentary behavior" typically refers to sitting/lying behavior rather than a simple absence of MVPA (moderate-to-vigorous intensity physical activity).

Eliminating these behaviors and promoting active lifestyles will be a factor delaying the occurrence of physical weakness and diseases, thus significantly reducing the cost of health care [3].

\section{Aim of the research}

The evaluation of the prevalence of sedentary life among the inhabitants of the city of Kielce, taking into account gender, education, body mass index (BMI), and civilization diseases.

\section{Material and methods}

The analysis included the data from the PONSHealthy Kielce study. The study was conducted in 2012-2013. The analysis used the data related to gender, education, and the values of anthropometric indicators such as BMI, WHR, and WC derived from 4,777 (1,613 males and 3,164 females) study participants. The age of the participants ranged from 37 to 66 years (mean age, 56.3 years).

The largest group of the study participants declared the completion of secondary education (46\%) and higher education (35\%) (3\% - primary, 12\% - vocational, 4\% - uncompleted university). Approximately 75\% of the participants were married and nearly $7 \%$ were single.

The largest group of the study participants was represented by pensioners (31\%) and persons employed in companies on the basis of an employment contract (44\%). Most of them indicated working as "specialists" (34\%), followed by "office workers" (17\%), "government representatives, senior officials and managers" (13\%), and "personal service workers and sales specialists” (13\%).

Body weight was assessed using body composition analyzer TANITA BC 554. BMI of the Healthy Kielce study participants was calculated based on anthropometric measurements of height and weight, as the ratio of body weight $(\mathrm{kg}) /$ height $\left(\mathrm{m}^{2}\right)$. The values of a continuous variable of BMI of the study participants were divided into 3 categories. Based on WHO guidelines, equally for men and women, normal weight patients reported BMI $<25 \mathrm{~kg} / \mathrm{m}^{2}$, overweight patients $-25 \mathrm{~kg} / \mathrm{m}^{2} \geq \mathrm{BMI}<30 \mathrm{~kg} / \mathrm{m}^{2}$, obese patients - BMI $\geq 30 \mathrm{~kg} / \mathrm{m}^{2}$. The WHR value was calculated on the basis of the waist/hip circumference. The categories of WHR for women and men, respectively, were qualified based on its value (standard WHR $<0.8 / 0.94$; abdominal obesity WHR $\geq 0.8 / 0.94$ ). The categories of WC for men and women were set based on waist circumference (WC standard value $<88 / 102$; abdominal obesity $W C \geq 88 / 102$ ).

The results of the average BMI of the study group were $27.78 \mathrm{~kg} / \mathrm{m}^{2}$. Normal BMI was related to $27 \%$, whereas overweight and obesity to $56 \%$ and $27 \%$ of the study participants. $30 \%$ of the participants reported standard WHR, and 70\% reported abdominal obesity. Standard WC was reported in $59.7 \%$ of cases.

$38 \%$ of the study participants declared diagnosed with hypertension, 7\% heart failure, and 9\% coronary heart disease. $1.5 \%$ of participants suffered a stroke and 5\% had diabetes. Asthma was diagnosed in $4 \%$ of participants, chronic obstructive pulmonary disease (COPD) in $0.7 \%$, and cancer in $3.4 \%$. Most common cancers were located in the "chest" (24\%) and "the cervix, the stem, the ovary" (21\%).

The questionnaire also included questions about sedentary lifestyle: the amount of time per week spent sitting on weekdays (min/day), holidays (min/ day), the total sitting time (min/week), the average sitting time (min/day), the total sitting time including travel time (min/week), and the time spent watching television (hrs/week). 
Table 1. Characteristics of research group

\begin{tabular}{|c|c|c|c|}
\hline Socio-economic features & Variable & Number & Percent \\
\hline \multirow[t]{2}{*}{ Gender } & Men & 3,164 & 66.3 \\
\hline & Women & 1,613 & 33.7 \\
\hline \multirow[t]{5}{*}{ Education } & Primary education & 142 & 2.9 \\
\hline & Vocational education & 576 & 12.1 \\
\hline & Secondary education & 2,193 & 45.9 \\
\hline & Uncompleted university education & 204 & 4.3 \\
\hline & Higher education & 1,662 & 34.8 \\
\hline \multirow[t]{7}{*}{ Marital status } & Widow/widower & 382 & 7.9 \\
\hline & Married & 3,601 & 75.4 \\
\hline & Divorced & 421 & 8.8 \\
\hline & Miss/bachelor & 314 & 6.6 \\
\hline & Living in separation & 17 & 0.4 \\
\hline & In drumble non-connection & 39 & 0.8 \\
\hline & Refusal & 3 & 0.1 \\
\hline \multirow[t]{4}{*}{ BMI } & $<18.5 \mathrm{~kg} / \mathrm{m}^{2}-$ underweight & 17 & 0.4 \\
\hline & $18.5-24.9 \mathrm{~kg} / \mathrm{m}^{2}-$ normal weight & 1,301 & 27.3 \\
\hline & $25.0-29.9 \mathrm{~kg} / \mathrm{m}^{2}$ - overweight & 2,179 & 45.6 \\
\hline & $\geq 30.0 \mathrm{~kg} / \mathrm{m}^{2}-$ obesity & 1,279 & 26.8 \\
\hline \multirow[t]{4}{*}{ WHR } & Standard value - women & 849 & 17.8 \\
\hline & Standard value - men & 601 & 12.6 \\
\hline & Abdominal obesity - women & 2,314 & 48.4 \\
\hline & Abdominal obesity - men & 1,011 & 21,2 \\
\hline \multirow[t]{4}{*}{ WC } & Standard value - women & 1,812 & 38.0 \\
\hline & Standard value - men & 1,037 & 21.7 \\
\hline & Abdominal obesity - women & 1,351 & 28.3 \\
\hline & Abdominal obesity - men & 575 & 12.0 \\
\hline
\end{tabular}

The analysis of the results was performed using the statistical package PQStat ver. 1.6. The differences in the time spent sitting, depending on the groups, were analyzed using Student' $t$-test (in order to compare two groups) or one-way ANOVA (in order to compare more groups $\mathrm{k}>2$ ). The test probability of $p<0.05$ was regarded as statistically significant, and the test probability of $p<0.01$ was regarded as highly statistically significant.

Due to the size of the group, parametric tests were used to evaluate the differences between the analyzed groups. Homogeneity of variance was tested in groups. In the case of non-homogeneity, correction was made, and the results were tested without correc- tion and after it. The lack of information about the use of the post-hoc test and the presence of the results of this test in the Tables is due to the ranking nature of the grouping scales, which allows them to be sorted in increasing order. If the result shows that there were statistically significant differences, information on the occurrence of the trend was reported (Table 1).

\section{Results}

The average time spent sitting on weekdays was $305.5 \mathrm{~min} /$ day (SD 164.6) and at weekends - 257.3 $\mathrm{min} /$ day (SD 128.5). The average total sitting time was 2,006.7 min/week (SD 960.4) (33.4 hrs/week; SD 
Table 2. Results of the relationship between sedentary lifestyle and sex

\begin{tabular}{|c|c|c|c|c|c|}
\hline Variable & Gender & Arithmetic mean & Median & Standard deviation & $p$ value \\
\hline \multirow{2}{*}{$\begin{array}{l}\text { The amount of time per week spent } \\
\text { sitting on weekdays (minutes/day) }\end{array}$} & Women & 302.2 & 300 & 164.1 & \multirow[t]{2}{*}{0.0765} \\
\hline & Men & 311.2 & 300 & 165.5 & \\
\hline \multirow{2}{*}{$\begin{array}{l}\text { The amount of time per week spent } \\
\text { sitting at weekends (minutes/day) }\end{array}$} & Women & 248.8 & 240 & 121.0 & \multirow[t]{2}{*}{$<0.0001$} \\
\hline & Men & 274.1 & 240 & 140.5 & \\
\hline \multirow[t]{2}{*}{ The total sitting time (hours/week) } & Women & 32.96 & 30 & 15.8 & \multirow[t]{2}{*}{0.0037} \\
\hline & Men & 34.39 & 32 & 16.3 & \\
\hline \multirow[t]{2}{*}{ The average sitting time (minutes/day) } & Women & 282.6 & 257.1 & 135.6 & \multirow[t]{2}{*}{0.0037} \\
\hline & Men & 294.7 & 274.3 & 139.9 & \\
\hline \multirow{2}{*}{$\begin{array}{l}\text { The total sitting time including travel } \\
\text { time (minutes/week) }\end{array}$} & Women & $2,015.7$ & 1,860 & 951.1 & \multirow[t]{2}{*}{0.0007} \\
\hline & Men & $2,115.4$ & 1,980 & 991.5 & \\
\hline \multirow{2}{*}{$\begin{array}{l}\text { The time spent watching television } \\
\text { (hours/week) }\end{array}$} & Women & 3.7 & 4 & 1.2 & \multirow[t]{2}{*}{$<0.0001$} \\
\hline & Men & 3.8 & 4 & 1.2 & \\
\hline
\end{tabular}

160.0). The average of the average sitting time was $286.7 \mathrm{~min} /$ day (SD, 137.2), and total sitting time including travel time was 2,049.4 min/week (SD 966.0). The largest group of participants (38.7\%) declared that they spent $11-20$ hours per week watching TV.

In the case of the time spent sitting on days off, the total, average sitting time, the total sitting time including travel time as well as the time spent watching $\mathrm{TV}$, the difference between the genders was highly statistically significant $(p<0.01)$ and higher scores related to men (Table 2).

The time spent sitting on weekdays was highly statistically significantly different $(p<0.01)$ depending on education, and the results increased with the higher level of education. In the case of time spent in a sitting position on weekends, the difference was not significant $(p>0.05)$. Total and average sitting time was highly statistically significantly different $(p<0.01)$ between the groups in terms of education, and these results increased with the higher level of education. The total time spent on sitting together with travel time was also highly statistically significant different $(p<0.01)$ between the groups, and these results increased with the higher level of education. The time spent watching TV was highly statistically significantly different $(p<0.01)$, varied depending on education, and these results decreased with the higher level of education (Table 3).

The time spent in the sitting position on days off differed highly significantly $(p<0.01)$ depending on the BMI, and the lowest results referred to a group of people with standard BMI. The time spent watching television was highly significant different $(p<0.01)$ depending on the BMI, and these results increased with increasing BMI (Table 4).
The relationship between the amount of time spent sitting and various diseases (diabetes, hypertension, coronary artery disease, heart failure, stroke, asthma, COPD, cancer) was also analyzed (Table 5).

In the case of time spent in a sitting position at weekends depending on the occurrence of diabetes, the difference was significant $(p<0.05)$ and higher scores were related to people with diabetes. The time spent watching TV was highly significantly $(p<0.01)$ among people with diabetes (Table 6).

In the case of the time spent in the sitting position depending on the occurrence of hypertension, the difference was significant $(p<0.05)$ and higher results were related to people with hypertension. The time spent watching TV was highly significantly $(p<0.01)$ in patients with hypertension (Table 7).

In the case of coronary artery disease, the amount of time spent in a sitting position on days off proved highly significant $(p<0.01)$, and higher results were reported in people with such a disease. Also, time spent watching TV was significantly higher $(p<0.05)$ among patients with coronary artery disease (Table 8 ).

The time spent sitting on weekdays, the total and average sitting time and the sitting time including travel time differed highly significantly $(p<0.01)$ depending on the occurrence of heart failure, and higher results were reported in people who did not suffer from the disease (Table 9).

The results of the scales of time spent sitting did not differ significantly ( $p>0.05$ ) depending on the occurrence of stroke and asthma (Table 10 and 11).

The results of the scales of time spent sitting did not differ significantly ( $p>0.05$ ) depending on the occurrence of COPD, except for the time spent watching television, where the difference was highly 
Table 3. Results of the relationship between sedentary lifestyle and level of education

\begin{tabular}{|c|c|c|c|c|c|}
\hline Variable & & $\begin{array}{l}\text { Arithmetic } \\
\text { mean }\end{array}$ & Median & $\begin{array}{l}\text { Standard } \\
\text { deviation }\end{array}$ & $p$ value \\
\hline \multirow{5}{*}{$\begin{array}{l}\text { The amount of time per } \\
\text { week spent sitting on } \\
\text { weekdays (minutes/day) }\end{array}$} & Primary education & 254.6 & 240 & 119.1 & \multirow[t]{5}{*}{$<0.0001$} \\
\hline & Vocational education & 253.3 & 240 & 142.1 & \\
\hline & Secondary education & 288.8 & 240 & 163.0 & \\
\hline & $\begin{array}{c}\text { Uncompleted university } \\
\text { education }\end{array}$ & 314.1 & 300 & 155.7 & \\
\hline & Higher education & 348.4 & 300 & 168.3 & \\
\hline \multirow{5}{*}{$\begin{array}{l}\text { The amount of time per } \\
\text { week spent sitting at } \\
\text { weekends (minutes/day) }\end{array}$} & Primary education & 266.8 & 240 & 139.5 & \multirow[t]{5}{*}{0.3701} \\
\hline & Vocational education & 266.0 & 240 & 130.5 & \\
\hline & Secondary education & 255.9 & 240 & 129.2 & \\
\hline & $\begin{array}{l}\text { Uncompleted university } \\
\text { education }\end{array}$ & 250.8 & 240 & 119.5 & \\
\hline & Higher education & 256.1 & 240 & 126.9 & \\
\hline \multirow{5}{*}{$\begin{array}{l}\text { The total sitting time } \\
\text { (hours/week) }\end{array}$} & Primary education & 29,75 & 28 & 12.72 & \multirow{5}{*}{$<0.0001$} \\
\hline & Vocational education & 29.43 & 28 & 14,43 & \\
\hline & Secondary education & 32.12 & 30 & 15.90 & \\
\hline & $\begin{array}{l}\text { Uncompleted university } \\
\text { education }\end{array}$ & 34.02 & 33 & 15.13 & \\
\hline & Higher education & 36.83 & 35 & 16.38 & \\
\hline \multirow{5}{*}{$\begin{array}{l}\text { The average sitting time } \\
\text { (minutes/day) }\end{array}$} & Primary education & 255.0 & 240 & 109.0 & \multirow[t]{5}{*}{$<0.0001$} \\
\hline & Vocational education & 252.2 & 240 & 123.7 & \\
\hline & Secondary education & 275.3 & 257.1 & 136.3 & \\
\hline & $\begin{array}{l}\text { Uncompleted university } \\
\text { education }\end{array}$ & 291.6 & 282.9 & 129.7 & \\
\hline & Higher education & 315.7 & 300 & 140.4 & \\
\hline \multirow{5}{*}{$\begin{array}{l}\text { The total sitting time } \\
\text { including travel time } \\
\text { (minutes/week) }\end{array}$} & Primary education & 1,826 & 1,770 & 779.8 & \multirow[t]{5}{*}{$<0.0001$} \\
\hline & Vocational education & 1,808 & 1,722 & 872 & \\
\hline & Secondary education & 1,969 & 1,810 & 961.2 & \\
\hline & $\begin{array}{l}\text { Uncompleted university } \\
\text { education }\end{array}$ & 2,088 & 2,030 & 914.3 & \\
\hline & Higher education & 2,253 & 2,160 & 985.9 & \\
\hline \multirow{5}{*}{$\begin{array}{l}\text { The time spent watching } \\
\text { television (hours/week) }\end{array}$} & Primary education & 3.94 & 4 & 1.22 & \multirow[t]{5}{*}{$<0.0001$} \\
\hline & Vocational education & 3.95 & 4 & 1.20 & \\
\hline & Secondary education & 3,83 & 4 & 1,18 & \\
\hline & $\begin{array}{l}\text { Uncompleted university } \\
\text { education }\end{array}$ & 3.68 & 4 & 1.11 & \\
\hline & Higher education & 3.53 & 4 & 1.14 & \\
\hline
\end{tabular}


Table 4. Results of the relationship between sedentary lifestyle and BMI results

\begin{tabular}{|c|c|c|c|c|c|}
\hline Variable & & $\begin{array}{l}\text { Arithmetic } \\
\text { mean }\end{array}$ & Median & $\begin{array}{l}\text { Standard } \\
\text { deviation }\end{array}$ & $p$ value \\
\hline \multirow{4}{*}{$\begin{array}{l}\text { The amount of time per } \\
\text { week spent sitting on } \\
\text { weekdays (minutes/day) }\end{array}$} & Underweight & 273.75 & 240 & 140.23 & \multirow{4}{*}{0.1617} \\
\hline & Normal weight & 306.68 & 300 & 140.23 & \\
\hline & Overweight & 300.31 & 240 & 162.69 & \\
\hline & Obesity & 312.67 & 300 & 160.38 & \\
\hline \multirow{4}{*}{$\begin{array}{l}\text { The amount of time per } \\
\text { week spent sitting at } \\
\text { weekends (minutes/day) }\end{array}$} & Underweight & 262.65 & 240 & 137.81 & \multirow{4}{*}{$<0.0001$} \\
\hline & Normal weight & 244.83 & 240 & 118.50 & \\
\hline & Overweight & 257.85 & 240 & 133.21 & \\
\hline & Obesity & 269.09 & 240 & 128.88 & \\
\hline \multirow{4}{*}{$\begin{array}{l}\text { The total sitting time } \\
\text { (hours/week) }\end{array}$} & Underweight & 30.22 & 28 & 12.52 & \multirow{4}{*}{0.0800} \\
\hline & Normal weight & 33.18 & 30 & 16.37 & \\
\hline & Overweight & 33.07 & 31 & 15.77 & \\
\hline & Obesity & 34.40 & 32 & 16.05 & \\
\hline \multirow{4}{*}{$\begin{array}{l}\text { The average sitting time } \\
\text { (minutes/day) }\end{array}$} & Underweight & 259.07 & 240 & 107.35 & \multirow{4}{*}{0.0800} \\
\hline & Normal weight & 284.43 & 257.14 & 140.35 & \\
\hline & Overweight & 283.47 & 265.71 & 135,16 & \\
\hline & Obesity & 294.84 & 274.28 & 137.54 & \\
\hline \multirow{4}{*}{$\begin{array}{l}\text { The total sitting time } \\
\text { including travel time } \\
\text { (minutes/week) }\end{array}$} & Underweight & $1,846.47$ & 1,690 & 750.33 & \multirow{4}{*}{0.0827} \\
\hline & Normal weight & $2,032.78$ & 1,870 & 985.02 & \\
\hline & Overweight & $2,027.73$ & 1,880 & 952.27 & \\
\hline & Obesity & $2,106.39$ & 1,980 & 970.91 & \\
\hline \multirow{4}{*}{$\begin{array}{l}\text { The time spent watching } \\
\text { television (hours/week) }\end{array}$} & Underweight & 3.23 & 3 & 1.5626 & \multirow{4}{*}{$<0.0001$} \\
\hline & Normal weight & 3.55 & 4 & 1.17 & \\
\hline & Overweight & 3.72 & 4 & 1.15 & \\
\hline & Obesity & 3.97 & 4 & 1.19 & \\
\hline
\end{tabular}

significant $(p<0.01)$, and more time watching television was spent by people with COPD than those without the condition (Table 12).

The time spent sitting on weekdays differed highly significantly $(p<0.01)$ depending on the occurrence of cancer, and higher results were reported in people without the disease. In the case of time spent in a sitting position at weekends, the difference was not significant $(p>0.05)$. The total and average sitting time differed highly significantly $(p<0.01)$ between groups, and higher results were reported in the group free from the disease. The total sitting time including travel time differed highly significantly $(p<0.01)$ depending on the occurrence of cancer, and higher results were reported in people without the disease.
The time spent watching TV was not significantly different $(p>0.05)$ between the groups (Table 13).

In the case of the time spent in the sitting position at weekends depending on the number of diseases, the difference was highly significant $(p<0.01)$, and the results increased with the higher number of the diseases. Also, the time spent watching television was highly significantly different $(p<0.01)$ depending on the number of diseases, and the results increased with the higher number of diseases (Table 14).

\section{Discussion}

In the last ten years, the behavior associated with a sedentary lifestyle has emerged as a new risk factor influencing health. Behaviors associated with seden- 
Table 5. Occurrence of diseases in the surveyed group

\begin{tabular}{|c|c|c|c|}
\hline Disease entity & Occurrence of the disease & Number & Percentage \\
\hline \multirow[t]{3}{*}{ Diabetes } & Yes & 250 & 5.233 \\
\hline & No & 4,523 & 94.683 \\
\hline & I do not know & 4 & 0.084 \\
\hline \multirow[t]{3}{*}{ Hypertension } & Yes & 1,796 & 37.597 \\
\hline & No & 2,973 & 62.236 \\
\hline & I do not know & 8 & 0.167 \\
\hline \multirow[t]{3}{*}{ Stroke } & Yes & 70 & 1.465 \\
\hline & No & 4,705 & 98.493 \\
\hline & I do not know & 2 & 0.042 \\
\hline \multirow[t]{3}{*}{ Coronary disease } & Yes & 443 & 9.274 \\
\hline & No & 4,324 & 90.517 \\
\hline & I do not know & 10 & 0.209 \\
\hline \multirow[t]{3}{*}{ Circulatory failure } & Yes & 314 & 6.573 \\
\hline & No & 4,447 & 93.092 \\
\hline & I do not know & 16 & 0.335 \\
\hline \multirow[t]{3}{*}{ Asthma } & Yes & 184 & 3.852 \\
\hline & No & 4,586 & 96.002 \\
\hline & I do not know & 7 & 0.147 \\
\hline \multirow[t]{3}{*}{ COPD } & Yes & 35 & 0.733 \\
\hline & No & 4,738 & 99.184 \\
\hline & I do not know & 4 & 0.084 \\
\hline \multirow[t]{3}{*}{ Tumor } & Yes & 163 & 3.412 \\
\hline & No & 4,603 & 96.358 \\
\hline & I do not know & 11 & 0.23 \\
\hline
\end{tabular}

tary lifestyles are characterized by forms of activity such as walking, which requires the energy expenditure at the level of 1.0 to 1.5 of the basal metabolism, sitting or resting.

Typical behaviors associated with sedentary lifestyles include watching television, using the computer, and the time spent sitting. Epidemiological studies carried out on different age groups show that a significant number of waking hours (without sleep) is spent on sitting, which poses new challenges to public health [4].

Our results showed that with the increase of the level of education, the amount of time spent sitting on weekdays increases, while the amount of time spent watching television decreases. With the increase of the level of education, the amount of total and average sitting time, including travel time also increases. The relationship between a sedentary lifestyle and education and other features is confirmed by Proper, who in his study of 1,048 adult Australians from areas of different socio-economic status showed that gender, age, socio-economic status, education, working time, and physical activity are associated with sitting time during weekdays, at weekends, and in spare time [5].

Our findings also evaluated the relationship between the amount of time spent sitting and BMI, and this relationship turned out to be highly significant. The time spent in the sitting position in spare time differed highly significantly $(p<0.01)$ depending on the BMI, and the lowest rates referred to a group of people with a standard BMI. Also, the time spent watching television was highly significantly different 
Table 6. Results of time spent sitting depending on the incidence of diabetes

\begin{tabular}{|c|c|c|c|c|c|}
\hline Variable & $\begin{array}{l}\text { Occurrence } \\
\text { of diabetes }\end{array}$ & $\begin{array}{l}\text { Arithmetic } \\
\text { mean }\end{array}$ & Median & $\begin{array}{l}\text { Standard } \\
\text { deviation }\end{array}$ & $p$ value \\
\hline \multirow{2}{*}{$\begin{array}{l}\text { The amount of time per week } \\
\text { spent sitting on weekdays } \\
\text { (minutes/day) }\end{array}$} & No & 305.23 & 300 & 164.93 & \multirow[t]{2}{*}{0.9992} \\
\hline & Yes & 305.22 & 300 & 160.02 & \\
\hline \multirow{2}{*}{$\begin{array}{l}\text { The amount of time per week } \\
\text { spent sitting at weekends } \\
\text { (minutes/day) }\end{array}$} & No & 256.43 & 240 & 128.58 & \multirow[t]{2}{*}{0.0401} \\
\hline & Yes & 273.56 & 240 & 125.55 & \\
\hline \multirow[t]{2}{*}{ The total sitting time (hours/week) } & No & 33,41 & 31 & 16.01 & \multirow[t]{2}{*}{0.4765} \\
\hline & Yes & 34.15 & 33 & 15.95 & \\
\hline \multirow{2}{*}{$\begin{array}{l}\text { The average sitting time } \\
\text { (minutes/day) }\end{array}$} & No & 286.34 & 265.71 & 137.22 & \multirow[t]{2}{*}{0.4765} \\
\hline & Yes & 292.69 & 282.86 & 136.75 & \\
\hline \multirow{2}{*}{$\begin{array}{l}\text { The total sitting time including } \\
\text { travel time (minutes/week) }\end{array}$} & No & $2,046.9$ & 1,890 & 965.74 & \multirow[t]{2}{*}{0.4593} \\
\hline & Yes & $2,093.4$ & $2,047.5$ & 971.54 & \\
\hline \multirow{2}{*}{$\begin{array}{l}\text { The time spent watching television } \\
\text { (hours/week) }\end{array}$} & No & 3.72 & 4 & 1.17 & \multirow[t]{2}{*}{0.0009} \\
\hline & Yes & 3.98 & 4 & 1.21 & \\
\hline
\end{tabular}

Table 7. Results of the amount of time spent sitting depending on the occurrence of hypertension

\begin{tabular}{|c|c|c|c|c|c|}
\hline Variable & $\begin{array}{c}\text { Occurrence } \\
\text { of hypertension }\end{array}$ & $\begin{array}{l}\text { Arithmetic } \\
\text { mean }\end{array}$ & Median & $\begin{array}{l}\text { Standard } \\
\text { deviation }\end{array}$ & $p$ value \\
\hline \multirow{2}{*}{$\begin{array}{l}\text { The amount of time per week } \\
\text { spent sitting on weekdays } \\
\text { (minutes/day) }\end{array}$} & No & 307.71 & 300 & 166.02 & \multirow[t]{2}{*}{0.1854} \\
\hline & Yes & 301.13 & 240 & 162.32 & \\
\hline \multirow{2}{*}{$\begin{array}{l}\text { The amount of time per week } \\
\text { spent sitting at weekends } \\
\text { (minutes/day) }\end{array}$} & No & 254.3 & 240 & 126.18 & \multirow[t]{2}{*}{0.0385} \\
\hline & Yes & 262.36 & 240 & 132.05 & \\
\hline \multirow[t]{2}{*}{ The total sitting time (hours/week) } & No & 33.53 & 31 & 16.03 & \multirow[t]{2}{*}{0.6189} \\
\hline & Yes & 33.3 & 30 & 15.97 & \\
\hline \multirow{2}{*}{$\begin{array}{l}\text { The average sitting time (minutes/ } \\
\text { day) }\end{array}$} & No & 287.44 & 265.71 & 137.4 & \multirow[t]{2}{*}{0.6189} \\
\hline & Yes & 285.4 & 257.14 & 136.88 & \\
\hline \multirow{2}{*}{$\begin{array}{l}\text { The total sitting time including } \\
\text { travel time (minutes/week) }\end{array}$} & No & $2,055.8$ & 1,920 & 968.48 & \multirow[t]{2}{*}{0.5541} \\
\hline & Yes & $2,038.7$ & 1,860 & 962.04 & \\
\hline \multirow{2}{*}{$\begin{array}{l}\text { The time spent watching television } \\
\text { (hours/week) }\end{array}$} & No & 3.66 & 4 & 1.16 & \multirow[t]{2}{*}{$<0.0001$} \\
\hline & Yes & 3.87 & 4 & 1.19 & \\
\hline
\end{tabular}

$(p<0.01)$ depending on the BMI, and these results increased with increasing BMI.

The above results were confirmed by the study conducted by Gennuso, who showed that more time spent on the behavior associated with a sedentary lifestyle was associated with higher BMI $(p<0.01)[6]$.

Similarly, in a study conducted by Stamatakis, free time spent on a sitting activity reported by study par- ticipants ( $\beta$ 0.088; 95\% CI: 0.047-0.130) was associated with BMI [7].

Gomez-Cabello, in turn, showed that sitting for more than four hours a day increased the risk of overweight (OR 1.7; 95\% CI: 1.06-2.82) and obesity (OR 2.7; 95\% CI: 1.62-4.66). In a similar study, Gomez-Cabello showed that sitting for more than four hours per day increased the risk of overweight/obesity (OR 1.42; 
Table 8. Results of time spent sitting depending on the occurrence of coronary artery disease

\begin{tabular}{|c|c|c|c|c|c|}
\hline Variable & $\begin{array}{l}\text { Occurrence of coronary } \\
\text { artery disease }\end{array}$ & $\begin{array}{l}\text { Arithmetic } \\
\text { mean }\end{array}$ & Median & $\begin{array}{l}\text { Standard } \\
\text { deviation }\end{array}$ & $p$ value \\
\hline \multirow{2}{*}{$\begin{array}{l}\text { The amount of time per week } \\
\text { spent sitting on weekdays } \\
\text { (minutes/day) }\end{array}$} & No & 306.86 & 300 & 165.67 & \multirow[t]{2}{*}{0.0248} \\
\hline & Yes & 289.3 & 300 & 153.65 & \\
\hline \multirow{2}{*}{$\begin{array}{l}\text { The amount of time per week } \\
\text { spent sitting at weekends } \\
\text { (minutes/day) }\end{array}$} & No & 255.46 & 240 & 126.93 & \multirow[t]{2}{*}{0.0043} \\
\hline & Yes & 275.54 & 240 & 141.37 & \\
\hline \multirow[t]{2}{*}{ The total sitting time (hours/week) } & No & 33.51 & 31 & 16.07 & \multirow[t]{2}{*}{0.3605} \\
\hline & Yes & 32.78 & 31 & 15.36 & \\
\hline \multirow{2}{*}{$\begin{array}{l}\text { The average sitting time (minutes/ } \\
\text { day) }\end{array}$} & No & 287.25 & 265.71 & 137.74 & \multirow[t]{2}{*}{0.3605} \\
\hline & Yes & 280.99 & 265.71 & 131.7 & \\
\hline \multirow{2}{*}{$\begin{array}{l}\text { The total sitting time including } \\
\text { travel time (minutes/week) }\end{array}$} & No & $2,053.5$ & $1,902.5$ & 970.11 & \multirow[t]{2}{*}{0.3541} \\
\hline & Yes & $2,008.9$ & 1,920 & 924.91 & \\
\hline \multirow{2}{*}{$\begin{array}{l}\text { The time spent watching television } \\
\text { (hours/week) }\end{array}$} & No & 3.72 & 4 & 1.17 & \multirow[t]{2}{*}{0.0113} \\
\hline & Yes & 3.87 & 4 & 1.22 & \\
\hline
\end{tabular}

Table 9. Results of the amount of time spent sitting depending on the occurrence of heart failure

\begin{tabular}{|c|c|c|c|c|c|}
\hline Variable & $\begin{array}{c}\text { Occurrence } \\
\text { of circulatory failure }\end{array}$ & $\begin{array}{l}\text { Arithmetic } \\
\text { mean }\end{array}$ & Median & $\begin{array}{l}\text { Standard } \\
\text { deviation }\end{array}$ & $p$ value \\
\hline \multirow{2}{*}{$\begin{array}{l}\text { The amount of time per week } \\
\text { spent sitting on weekdays } \\
\text { (minutes/day) }\end{array}$} & No & 307.13 & 300 & 164.03 & \multirow[t]{2}{*}{0.0027} \\
\hline & Yes & 277.66 & 240 & 171.4 & \\
\hline \multirow{2}{*}{$\begin{array}{l}\text { The amount of time per week } \\
\text { spent sitting at weekends } \\
\text { (minutes/day) }\end{array}$} & No & 257.15 & 240 & 127.57 & \multirow[t]{2}{*}{0.735} \\
\hline & Yes & 259.92 & 240 & 140,72 & \\
\hline \multirow[t]{2}{*}{ The total sitting time (hours/week) } & No & 33.63 & 31 & 15.95 & \multirow[t]{2}{*}{0.0026} \\
\hline & Yes & 30.82 & 28 & 16.61 & \\
\hline \multirow{2}{*}{$\begin{array}{l}\text { The average sitting time (minutes/ } \\
\text { day) }\end{array}$} & No & 288.26 & 265.71 & 136.7 & \multirow[t]{2}{*}{0.0026} \\
\hline & Yes & 264.14 & 240 & 142.35 & \\
\hline \multirow{2}{*}{$\begin{array}{l}\text { The total sitting time including } \\
\text { travel time (minutes/week) }\end{array}$} & No & $2,060.8$ & 1,920 & 962.86 & \multirow[t]{2}{*}{0.002} \\
\hline & Yes & $1,886.8$ & 1,740 & 997.07 & \\
\hline \multirow{2}{*}{$\begin{array}{l}\text { The time spent watching television } \\
\text { (hours/week) }\end{array}$} & No & 3.74 & 4 & 1.17 & \multirow[t]{2}{*}{0.9242} \\
\hline & Yes & 3.73 & 4 & 1.27 & \\
\hline
\end{tabular}

95\% CI: 1.06-1.89) and excess fat (OR 1.4; 95\% CI: 1.14$1.74)$ in women and risk of central obesity (OR 1.74; 95\% CI: 1.21-2.49) in men [8].

Stamatakis also showed that the time spent watching television ( $\beta$ 0.159; 95\% CI: 0.0104-0.215) was positively associated with BMI [7].

In the study, which assessed the sedentary behavior in transport, Frank showed that $\geq 1$ hour a day sitting in the car was not associated with overweight (OR 0.86; 95\% CI: $0.51-1.22$ ) or obesity (OR 0.67; 95\% CI: 0.41-1.06) [9].

Bullock in the study of 5,338 people from the UK, the USA, Germany, Spain, Italy, France, Portugal, Austria, and Switzerland rated BMI, total physical activity (MET-minutes/week), and sitting time (hours/ day). Participants were grouped into quartiles based 
Table 10. Results of sitting time spent depending on the occurrence of stroke

\begin{tabular}{|c|c|c|c|c|c|}
\hline Variable & $\begin{array}{l}\text { Occurrence } \\
\text { of stroke }\end{array}$ & Arithmetic mean & Median & $\begin{array}{l}\text { Standard } \\
\text { deviation }\end{array}$ & $p$ value \\
\hline \multirow{2}{*}{$\begin{array}{l}\text { The amount of time per week } \\
\text { spent sitting on weekdays } \\
\text { (minutes/day) }\end{array}$} & No & 305.53 & 300 & 164.48 & \multirow[t]{2}{*}{0.3074} \\
\hline & Yes & 285 & 240 & 176.34 & \\
\hline \multirow{2}{*}{$\begin{array}{l}\text { The amount of time per week } \\
\text { spent sitting at weekends } \\
\text { (minutes/day) }\end{array}$} & No & 257.47 & 240 & 128.79 & \multirow[t]{2}{*}{0.4503} \\
\hline & Yes & 247.83 & 240 & 104.39 & \\
\hline \multirow[t]{2}{*}{ The total sitting time (hours/week) } & No & 33.48 & 31 & 15.99 & \multirow[t]{2}{*}{0.2401} \\
\hline & Yes & 31.21 & 28 & 16.95 & \\
\hline \multirow{2}{*}{$\begin{array}{l}\text { The average sitting time (minutes/ } \\
\text { day) }\end{array}$} & No & 286.96 & 265.71 & 137.06 & \multirow[t]{2}{*}{0.2401} \\
\hline & Yes & 267.5 & 240 & 145.3 & \\
\hline \multirow{2}{*}{$\begin{array}{l}\text { The total sitting time including } \\
\text { travel time (minutes/week) }\end{array}$} & No & $2,051.4$ & 1,920 & 965.2 & \multirow[t]{2}{*}{0.2385} \\
\hline & Yes & $1,914.3$ & 1,750 & $1,014.9$ & \\
\hline \multirow{2}{*}{$\begin{array}{l}\text { The time spent watching television } \\
\text { (hours/week) }\end{array}$} & No & 3.74 & 4 & 1.18 & \multirow[t]{2}{*}{0.6581} \\
\hline & Yes & 3.8 & 4 & 1.22 & \\
\hline
\end{tabular}

Table 11. Results of time spent sitting depending on the occurrence of asthma

\begin{tabular}{|c|c|c|c|c|c|}
\hline Variable & $\begin{array}{l}\text { Occurrence } \\
\text { of asthma }\end{array}$ & Arithmetic mean & Median & $\begin{array}{l}\text { Standard } \\
\text { deviation }\end{array}$ & $p$ value \\
\hline \multirow{2}{*}{$\begin{array}{l}\text { The amount of time per week } \\
\text { spent sitting on weekdays } \\
\text { (minutes/day) }\end{array}$} & No & 305.13 & 300 & 164.98 & \multirow[t]{2}{*}{0.8314} \\
\hline & Yes & 307.79 & 300 & 156.79 & \\
\hline \multirow{2}{*}{$\begin{array}{l}\text { The amount of time per week } \\
\text { spent sitting at weekends } \\
\text { (minutes/day) }\end{array}$} & No & 256.94 & 240 & 128.27 & \multirow[t]{2}{*}{0.294} \\
\hline & Yes & 267.1 & 240 & 133.26 & \\
\hline \multirow[t]{2}{*}{ The total sitting time (hours/week) } & No & 33.42 & 31 & 16.02 & \multirow[t]{2}{*}{0.5798} \\
\hline & Yes & 34.09 & 33 & 15.75 & \\
\hline \multirow{2}{*}{$\begin{array}{l}\text { The average sitting time (minutes/ } \\
\text { day) }\end{array}$} & No & 286.45 & 265.71 & 137.29 & \multirow[t]{2}{*}{0.5798} \\
\hline & Yes & 292.17 & 282.85 & 135.01 & \\
\hline \multirow{2}{*}{$\begin{array}{l}\text { The total sitting time including } \\
\text { travel time (minutes/week) }\end{array}$} & No & 2,048 & 1,890 & 966.83 & \multirow[t]{2}{*}{0.6095} \\
\hline & Yes & $2,085.1$ & $2,017.5$ & 947.06 & \\
\hline \multirow{2}{*}{$\begin{array}{l}\text { The time spent watching television } \\
\text { (hours/week) }\end{array}$} & No & 3.74 & 4 & 1.17 & \multirow[t]{2}{*}{0.9006} \\
\hline & Yes & 3.75 & 4 & 1.31 & \\
\hline
\end{tabular}

on their daily sitting time $(<4,4-\leq 6,6-\leq 8$, and $>8$ hours/day). Studies have shown that the participants in the highest sitting time quartile ( $\geq 8$ hours/ day) had $62 \%$ higher chances for obesity compared to participants in the lowest quartile $(<4$ hours/ day), after adjustment for physical activity and other confounding variables (OR 1.62; 95\% CI: 1.24-2.12, $p<0.01)$. The author showed that the sitting time is associated with obesity, independent of physical activity [10].

In our study, we evaluated WHR and WC indexes, which indicated that standard WHR was reported in $30 \%$ of participants and abdominal obesity in $70 \%$ of cases. Standard WC was observed only in $29 \%$ of cases. The relation between abdominal obesity and a sedentary lifestyle was not analyzed. 
Table 12. Results of the amount of time spent sitting depending on the occurrence of COPD

\begin{tabular}{|c|c|c|c|c|c|}
\hline Variable & $\begin{array}{l}\text { Occurrence } \\
\text { of COPD }\end{array}$ & Arithmetic mean & Median & $\begin{array}{l}\text { Standard } \\
\text { deviation }\end{array}$ & $p$ value \\
\hline \multirow{2}{*}{$\begin{array}{l}\text { The amount of time per week } \\
\text { spent sitting on weekdays } \\
\text { (minutes/day) }\end{array}$} & No & 304.98 & 300 & 164.41 & \multirow[t]{2}{*}{0.2175} \\
\hline & Yes & 339.43 & 300 & 194.66 & \\
\hline \multirow{2}{*}{$\begin{array}{l}\text { The amount of time per week } \\
\text { spent sitting at weekends } \\
\text { (minutes/day) }\end{array}$} & No & 257.07 & 240 & 128.48 & \multirow[t]{2}{*}{0.0979} \\
\hline & Yes & 293.14 & 300 & 124.14 & \\
\hline \multirow[t]{2}{*}{ The total sitting time (hours/week) } & No & 33.41 & 31 & 15.98 & \multirow[t]{2}{*}{0,0871} \\
\hline & Yes & 38.06 & 35 & 18.47 & \\
\hline \multirow{2}{*}{$\begin{array}{l}\text { The average sitting time (minutes/ } \\
\text { day) }\end{array}$} & No & 286.38 & 265.71 & 137 & \multirow[t]{2}{*}{0.0871} \\
\hline & Yes & 326.2 & 300 & 158.33 & \\
\hline \multirow{2}{*}{$\begin{array}{l}\text { The total sitting time including } \\
\text { travel time (minutes/week) }\end{array}$} & No & $2,047.4$ & 1,900 & 964.75 & \multirow[t]{2}{*}{0.0994} \\
\hline & Yes & 2,317.4 & 2,130 & $1,105.6$ & \\
\hline \multirow{2}{*}{$\begin{array}{l}\text { The time spent watching television } \\
\text { (hours/week) }\end{array}$} & No & 3.73 & 4 & 1.17 & \multirow[t]{2}{*}{0.0057} \\
\hline & Yes & 4.29 & 4 & 1.34 & \\
\hline
\end{tabular}

Table 13. Results of the amount of time spent sitting depending on the occurrence of tumor

\begin{tabular}{|c|c|c|c|c|c|}
\hline Variable & $\begin{array}{l}\text { Occurrence } \\
\text { of tumor }\end{array}$ & Arithmetic mean & Median & $\begin{array}{l}\text { Standard } \\
\text { deviation }\end{array}$ & $p$ value \\
\hline \multirow{2}{*}{$\begin{array}{l}\text { The amount of time per week } \\
\text { spent sitting on weekdays } \\
\text { (minutes/day) }\end{array}$} & No & 306.47 & 300 & 165.34 & \multirow[t]{2}{*}{0.0016} \\
\hline & Yes & 270.13 & 240 & 139.705 & \\
\hline \multirow{2}{*}{$\begin{array}{l}\text { The amount of time per week } \\
\text { spent sitting at weekends } \\
\text { (minutes/day) }\end{array}$} & No & 257.91 & 240 & 128.66 & \multirow[t]{2}{*}{0.0982} \\
\hline & Yes & 240.93 & 240 & 122.05 & \\
\hline \multirow[t]{2}{*}{ The total sitting time (hours/week) } & No & 33.57 & 31 & 16.06 & \multirow[t]{2}{*}{0.0015} \\
\hline & Yes & 29.94 & 28 & 14.07 & \\
\hline \multirow{2}{*}{$\begin{array}{l}\text { The average sitting time (minutes/ } \\
\text { day) }\end{array}$} & No & 287.73 & 265.71 & 137.63 & \multirow[t]{2}{*}{0.0015} \\
\hline & Yes & 256.63 & 240 & 120.6 & \\
\hline \multirow{2}{*}{$\begin{array}{l}\text { The total sitting time including } \\
\text { travel time (minutes/week) }\end{array}$} & No & $2,056.9$ & 1,920 & 969.46 & \multirow[t]{2}{*}{0.0012} \\
\hline & Yes & $1,836.4$ & 1,720 & 837.46 & \\
\hline \multirow{2}{*}{$\begin{array}{l}\text { The time spent watching television } \\
\text { (hours/week) }\end{array}$} & No & 3.74 & 4 & 1.18 & \multirow[t]{2}{*}{0.5227} \\
\hline & Yes & 3.8 & 4 & 1.13 & \\
\hline
\end{tabular}

However, Gardiner and Gomez-Cabello showed that the time spent sitting increased the risk of abdominal obesity by $80 \%$ (OR 1.8 ; $95 \%$ CI: $1.20-2.70$ ) in both sexes and by $81 \%$ in women (OR $1.8 ; 95 \% \mathrm{CI}$ : $1.21-2.70)[8,11]$.

Gennuso showed that longer time spent sitting was associated with a large waist circumference $(p=0.01)$. In the population of people who overcame colorectal cancer, the time spent on sitting behavior was not associated with waist circumference [6].

In the study conducted by Stamatakis, the time spent watching television ( $\beta$ 0.416; 95\% CI: 0.2750.558 ) and overall free time spent on the activity related with a sedentary lifestyle $(\beta \quad 0.234 ; 95 \% \mathrm{CI}$ : $0.129-0.339)$ was positively associated with waist circumference [7]. 
Table 14. Results of the amount of time spent sitting depending on the number of diseases

\begin{tabular}{|c|c|c|c|c|c|}
\hline Variable & $\begin{array}{l}\text { Number } \\
\text { of diseases }\end{array}$ & Arithmetic mean & Median & $\begin{array}{l}\text { Standard } \\
\text { deviation }\end{array}$ & $p$ value \\
\hline \multirow{6}{*}{$\begin{array}{l}\text { The amount of time per week } \\
\text { spent sitting on weekdays } \\
\text { (minutes/day) }\end{array}$} & 0 & 311 & 300 & 167 & \multirow[t]{6}{*}{0.0708} \\
\hline & 1 & 301 & 240 & 159 & \\
\hline & 2 & 294 & 270 & 172 & \\
\hline & 3 & 281 & 240 & 153 & \\
\hline & 4 & 310 & 300 & 153 & \\
\hline & 5 & 309 & 300 & 106 & \\
\hline \multirow{6}{*}{$\begin{array}{l}\text { The amount of time per week } \\
\text { spent sitting at weekends } \\
\text { (minutes/day) }\end{array}$} & 0 & 254 & 240 & 126 & \multirow[t]{6}{*}{0.004} \\
\hline & 1 & 259 & 240 & 131 & \\
\hline & 2 & 263 & 240 & 131 & \\
\hline & 3 & 257 & 240 & 117 & \\
\hline & 4 & 329 & 300 & 188 & \\
\hline & 5 & 326 & 300 & 133 & \\
\hline \multirow[t]{6}{*}{ The total sitting time (hours/week) } & 0 & 33.8 & 32 & 16.1 & \multirow[t]{6}{*}{0.272} \\
\hline & 1 & 33.2 & 30 & 15.6 & \\
\hline & 2 & 32.7 & 31 & 16.9 & \\
\hline & 3 & 31.4 & 28 & 15.2 & \\
\hline & 4 & 35.5 & 35 & 15.6 & \\
\hline & 5 & 36.6 & 35 & 12.5 & \\
\hline \multirow{6}{*}{$\begin{array}{l}\text { The average sitting time (minutes/ } \\
\text { day) }\end{array}$} & 0 & 290 & 274 & 138 & \multirow[t]{6}{*}{0.272} \\
\hline & 1 & 285 & 257 & 134 & \\
\hline & 2 & 280 & 266 & 145 & \\
\hline & 3 & 269 & 240 & 130 & \\
\hline & 4 & 304 & 300 & 133 & \\
\hline & 5 & 313 & 300 & 107 & \\
\hline \multirow{6}{*}{$\begin{array}{l}\text { The total sitting time including } \\
\text { travel time } \\
\text { (minutes/week) }\end{array}$} & 0 & 2,074 & 1,940 & 975 & \multirow[t]{6}{*}{0.241} \\
\hline & 1 & 2,033 & 1,860 & 940 & \\
\hline & 2 & 2,005 & 1,920 & 1,018 & \\
\hline & 3 & 1,922 & 1,820 & 909 & \\
\hline & 4 & 2,171 & 2,160 & 940 & \\
\hline & 5 & 2,230 & 2,100 & 736 & \\
\hline \multirow{6}{*}{$\begin{array}{l}\text { The time spent watching television } \\
\text { (hours/week) }\end{array}$} & 0 & 3.65 & 4 & 1.15 & \multirow[t]{6}{*}{$<0.0001$} \\
\hline & 1 & 3.82 & 4 & 1.17 & \\
\hline & 2 & 3.83 & 4 & 1.21 & \\
\hline & 3 & 3.94 & 4 & 1.23 & \\
\hline & 4 & 4.08 & 4 & 1.42 & \\
\hline & 5 & 4.71 & 5 & 1.5 & \\
\hline
\end{tabular}


Similarly, Gao showed that longer time spent on watching television was associated with high WHR (3.9; 95\% CI: $1.08-8.4 ; p=0.01$ ) [12].

The authors of the present study have also attempt to assess the relationship between sedentary lifestyles and the prevalence of diseases. Our findings analyzing the relation between the amount of time spent sitting with diabetes, have shown that in the case of the time spent in a sitting position at weekends, the difference is significant $(p<0.05)$, and higher scores are reported in people with diabetes. Also, the time spent watching TV was highly significantly higher $(p<0.01)$ among people with diabetes. However, it is not known whether sitting is a factor of exposure or the result of a disease because the study design for such an assessment does not allow for this type of assessment.

The observations made in patients with type 2 diabetes, which evaluated the relationship between physical activity related to the job performed, commuting to work and free time, and overall mortality and cardiovascular causes are also interesting. The study involved 3,316 patients with type 2 diabetes aged 25-74. Three levels of physical activity at work were distinguished: light physical activity - a simple physical work and sitting (e.g. office work), moderate physical activity - walking and standing (e.g. work of a shop assistant), and active physical activity - walking and moving heavy objects (e.g. working as a warehouseman). In the period of 18 years, $64 \%$ of deaths among patients were due to cardiac causes. After considering a number of parameters (age, sex, year of study, BMI, systolic blood pressure, cholesterol, smoking, and types of physical activity), which underwent modifications during the observation, it was showed that the participants actively spending their free time reported 30\% lower risk of death, and those moderately active, $15 \%$ lower risk compared with those who preferred a sedentary lifestyle. It was also observed that not only physical activity in leisure time, but also physical activity related to the job performed and commuting prevented deaths from cardiac causes in patients with type 2 diabetes. The results of the study showed that in patients with type 2 diabetes who walk a lot and carry various items during physical work, the risk of death from cardiac causes is lower by $40 \%$. Diabetic patients actively using their free time and following a proper diet can prevent the development of type 2 diabetes or delay it [13-16].

According to Sienkiewicz, aerobic exercise and strength training also allow for better glycemic control and reduce mortality in patients with type 2 diabetes, particularly in the sub-group of people with the highest risk of the disease [13].

In our study, we also evaluated the relationship between sedentary lifestyles and the occurrence of cardiovascular disease - hypertension, coronary artery disease, and heart failure. In the case of hypertension and coronary heart disease, the differences were highly significant and sitting time was higher in the group of people with the discussed diseases. Such relations were not observed in the case of heart failure. The patients in the study suffered from these diseases. There are also numerous publications confirming the importance of physical activity as a risk factor for cardiovascular disease.

Over 50 years ago, a pioneering work of Morris was published, which outlines the hypothesis concerning the relation between low physical activity and coronary heart disease (CHD) among London bus drivers. It was also documented that physical inactivity is a major risk factor for CHD in the Western population [13].

Barengo after studying 15,853 men and 16,824 women aged 30-59 living in Eastern and Southwestern Finland, showed that a sedentary lifestyle, which is the minimum level of activity both at work and at play, is associated with a statistically significant increase in the incidence of cardiovascular disease (CVD) and overall mortality among men and women. Cardiovascular disease and overall mortality were observed less frequently in people who were moderately or very physically active in their leisure time, compared with those leading a sedentary lifestyle. Also, moderate and high levels of occupational physical activity reduced the risk of CVD and mortality by $21-27 \%$ in both sexes. In women, walking at least 15 minutes a day or riding a bicycle to and from work, lower the incidence level of cardiovascular disease and reduced overall mortality. Therefore, the promotion of even a moderate level of physical activity in leisure time and at work, may play an important role in the prevention of premature CVD and overall mortality. The protective effect of physical activity on overall mortality was similar to the effect on mortality related to CVD, which may indicate that moderate and high levels of physical activity also protect patients from causes other than cardiovascular disease [17].

Ogum and Shinoda-Tagawa conducted a metaanalysis of 30 studies on the effects of physical activity on the occurrence of CVD in women. Based on the review of the research, covering a period of 37 years, the relationship between physical activity in women initially healthy and the incidence of CVD, especially CHD and stroke, was determined. Physical activity was associated with a reduction in the occurrence of cardiovascular disease in women. The results showed that physically inactive women would benefit even if they increased their physical activity only slightly (e.g. walking 1 hour a week or even less) and even greater benefits could be observed with the increase of physical activity [18].

Rastogi, assuming that the level of physical activity for people from urban areas in India is now compa- 
rable to that of the West, conducted a study to assess the relation between physical activity and the risk of CHD. The authors observed a positive correlation between the lack of activity outside work and the risk of CHD. Following a multivariate analysis, it was observed that people who spent more than 3.6 hours per day on "sitting activity" (e.g. watching television) compared with people spending less than 70 minutes a day, the risk level has increased to 1.88 (95\% CI: 1.09-3.20). Exercises performed during leisure time (equivalent to 35-40 minutes a day of brisk walk) protected against the development of CHD, while sedentary lifestyle positively correlated with the risk of coronary heart disease [19].

Protective effects of physical activity in different parts of the World were also demonstrated in a study INTER HEART. It was observed that a regular physical activity was significantly associated with a reduction in the incidence of acute myocardial infarction, independent of other risk factors [20]. According to Richardson's observation that individuals with high-risk of CVD benefit greatly from an active lifestyle [21].

Our findings regarding the amount of time spent on sitting did not differ significantly depending on the occurrence of stroke. The question is why the appearance of the disease, which often leads to patient's immobilization in bed and dependence on third parties, was not a motivating factor for the study participants to follow a more active lifestyle.

In a meta-analysis carried out by Wendel-Vos, which included a total of 31 publications, physical activity of medium intensity, compared with the absence of activity, protected participants against stroke both in the case of professional activity $(\mathrm{RR}=0.64$; 95\% CI: 0.87-0.48] and leisure time activity $(\mathrm{RR}=0.85 ; 95 \% \mathrm{CI}: 0.78-0.93)$. High levels of physical activity protect against ischemic stroke, both in comparison with moderate activity levels $(\mathrm{RR}=0.77$; 95\% CI: 0.60-0.98) and its absence at work $(\mathrm{RR}=0.57$; 95\% CI: 0.43-0.77). The results of research conducted in Europe showed a stronger protective effect of physical effort ( $R R=0.47$; 95\% CI: $0.33-0.66)$ than the results of observations conducted in the United States $(\mathrm{RR}=0.82 ; 95 \% \mathrm{CI}: 0.75-0.90)$. The lack of physical activity, however, was a modifiable risk factor for both the total stroke incidents and their subtypes [22]. In other meta-analyzes it was confirmed that the lack of physical activity was also an important risk factor for stroke. In some published studies, the protective effect of physical activity on stroke remains controversial [13].

The last analyzed group of diseases were cancers (malignant neoplasm). In this case, the results concerning the relationship between the amount of time spent sitting and the above group of diseases were different from other groups. The study participants reported that the amount of time spent sitting on week- days, the total, average sitting time, and the sitting time including travel time was significantly lower in relation to people with no such diseases. The data may indicate that cancer, which results in significant fear, is a factor that encourages patients to follow a more active lifestyle. It is also possible that these changes are related to medical advice.

The literature review conducted by Lynch, 18 articles related to behaviors associated with a sedentary lifestyle and cancer risk or behaviors associated with a sedentary lifestyle and health outcomes in cancer survivors were identified. Ten of these studies showed a statistically significant positive relationship between behavior related to a sedentary lifestyle and cancers. The behavior associated with a sedentary lifestyle was associated with an increased risk of developing colorectal cancer, endometrial cancer, ovarian cancer, and prostate cancer, increased mortality due to cancer in women, and weight gain in colon cancer survivors. A review of the literature on the behavior of sedentary lifestyles supported the hypothetical role of obesity and metabolic disorders, as causative mechanisms in the relationship between the behavior associated with a sedentary lifestyle and cancer [23].

According to Lee and Thune, physical activity of moderate intensity ( $>4.5 \mathrm{MET}$ ) performed by 30-60 minutes a day is associated also with a lower incidence of some cancers, especially colorectal cancer (in men and women 30-40\% lower) and breast cancer (in women $20-30 \%$ lower), in comparison with morbidity in patients whose physical activity is smaller [24, 25].

Tuchowska, in turn, states that abnormal body weight may increase the risk of colon and breast cancer, and regular exercises can significantly reduce the incidence of colon cancer. Physical activity also reduces the risk of breast cancer and endometrial cancer in women, and in men with prostate cancer [26].

In our study, we also highlighted the relationship between sedentary lifestyle and the number of occurring diseases. It seems that a sedentary lifestyle has a connection with the number of diseases, but to date, there has been no literature, to which any reference could be made. These relationships are particularly evident in relation to time spent sitting at weekends and watching TV.

Numerous scientific studies on sitting lifestyle pay attention to its relationship to mortality risk.

The study conducted by Martinez-Gomez showed that people who spent less than 8 hours a day sitting, showed a lower risk of all-cause mortality $(\mathrm{HR}=0.70$; 95\% CI: 0.60-0.82) compared with those in the same age, but following a sedentary lifestyle. Moreover, physically active people who do not follow a sedentary lifestyle (less than 8 hours a day sitting), showed a lower risk of all-cause mortality (HR 0.44; 95\% CI: $0.36-0.52)$ than those physically inactive and leading a sedentary lifestyle [27]. 
Similarly, Pavey observed that people who spent 8 to 11 hours a day sitting (HR 1.52; 95\% CI: 1.17-1.98), showed a higher risk of all-cause mortality than those who spent fewer than 8 hours a day sitting. With every hour spent sitting, the all-cause mortality risk increased by 3\% (HR 1.03; 95\% CI: 1.01-1.05). Furthermore, the risk of all-cause mortality in patients who were not physically active (less than 150 minutes of activity per week) and spent from 8 to 11 hours or over 11 hours a day sitting, increased by 31\% (HR 1.31; 95\% CI: 1.07-1.61) and 47\% (HR 1.47; 95\% CI: 1.15-1.93) [28].

By studying a population of people who overcame colorectal cancer, Campbell pointed out that more than 6 hours per day of leisure time spent sitting prior to the diagnosis, compared with less than 3 hours per day, were associated with a higher risk of all-cause mortality (RR 1.36; 95\% CI: 1.10-1.68) and a mortality resulting from other causes (not cardiovascular and not associated with colorectal cancer) (RR 1.48; 95\% CI: 1.05-2.08). The time spent sitting after the diagnosis (colon cancer) ( $>6$ hours) was associated with a higher risk of all-cause mortality (RR 1.27; 95\% CI: 0.99-1.64), and mortality resulting directly from colorectal cancer (RR 1.62; 95\% CI: 1.07-2.44) [29].

The results of the study by Warburton et al. who observed that in the patients with multiple risk factors, but who are at the same time regular exercisers, the likelihood of premature mortality is lower than in patients without risk factors who lead a sedentary life. Regular exercise can reduce total mortality by more than $50 \%$. The influence of physical activity on mortality was observed not only in the primary, but also for the secondary prevention of cardiovascular diseases [30].

The results of the presented studies revealed the extent of the problem of sedentary lifestyle and its health consequences. In view of the fact that in most societies a sedentary lifestyle begins to dominate, priority should be given to the introduction of recommendations regarding the implementation of regular physical activity from childhood to old age.

\section{Conclusions}

1. Men prefer a sedentary lifestyle more often than women.

2. With the increase in the level of education, the amount of time spent sitting on weekdays, the total and average sitting time, and the total sitting time including travel time increases, while the amount of time spent on watching television decreases.

3. Sedentary lifestyle is related with the values of body mass index. The study participants with a normal body mass index spend less time sitting on days off work, compared to overweight and obese people. With the increase in BMI, the amount of time spent on watching TV increases.

4. Cardiovascular diseases, respiratory diseases, and diabetes are associated with a sedentary lifestyle.
The amount of time spent sitting in people who suffer from these diseases is higher than in those without these diseases. Reverse dependencies are reported in the case of cancer, which for many patients may actually determine a lifestyle change.

5. Multiple morbidities lead to the increased amount of time spent sitting, and these relationships are particularly evident in relation to the time spent sitting on the days off and watching TV.

6. There is a need to implement prevention programs that promote physical activity among the residents of Kielce.

\section{Conflict of interest}

The authors declare no conflict of interest.

\section{References}

1. Biskup M, Król H, Opuchlik A, Macek P, Włoch A, Żak M. Rola aktywności fizycznej w utrzymaniu zdrowia po amputacji piersi. Studia Medyczne 2015; 31: 146-154.

2. Woźniewski M. Kultura fizyczna w życiu ludzi chorych na nowotwory złośliwe. Adv Clin Med 2002; 11: 103-108.

3. Wilmot EG, Edwardson CL, Achana FA, Davies MJ, Gorely T, Gray LJ, Khunti K, Yates T, Biddle SJ. Sedentary time in adults and the association with diabetes, cardiovascular disease and death: systematic review and meta-analysis. Diabetologia 2012; 55: 2895-2905.

4. Machado de Rezende LF, Rey-López JP, Mastudo VK, do Carmo Luiz O. Sedentary behavior and health outcomes among older adults: a systematic review. BMC Public Health 2014; 14: 1471-2458.

5. Proper KI, Cerin E, Brown WJ, Owen N. Sitting time and socio-economic differences in overweight and obesity. Int J Obesity 2007; 31: 169-176.

6. Gennuso KP, Gangnon RE, Matthews CE. Sedentary behavior, physical activity, and markers of health in older adults. Med Sci Sports Exerc 2013; 45: 1493.

7. Stamatakis E, Davis M, Stathi A, Hamer M. Associations between multiple indicators of objectively-measured and self-reported sedentary behavior and cardiometabolic risk in older adults. Prev Med 2012; 54: 82-87.

8. Gómez-Cabello A, Vicente-Rodriguez G, Pindado M, Vila S, Casajús JA, Pradas de la Fuente F, Ara I. Increased risk of obesity and central obesity in sedentary postmenopausal women. Nutr Hosp 2012; 27: 865-870 [Article in Spanish].

9. Frank L, Keer J, Rosenberg D, King A. Healthy aging and where you live: community design relationships with physical activity and body weight in older Americans. J Phys Act Health 2010; 7: 82-90.

10. Bullock VE, Griffiths P, Sherar LB, Clemes SA. Sitting time and obesity in a sample of adults from Europe and the USA. Ann Hum Biol 2017; 44: 230-236.

11. Gardiner PA, Healy GN, Eakin EG, Clark BK, Dunstan DW, Shaw JE, Zimmet PZ, Owen N. Associations between television viewing time and overall sitting time with the metabolic syndrome in older men and women: the Australian Diabetes, Obesity and Lifestyle study. J Am Geriatr Soc 2011; 59: 788-796. 
12. Gao X, Nelson ME, Tucker KL. Television viewing is associated with prevalence of metabolic syndrome in Hispanic elders. Diabetes Care 2007; 30: 694-700.

13. Sinkiewicz W, Gęsińska H, Kubica A, et al. Aktywność fizyczna a ryzyko chorób sercowo-naczyniowych. Cardiovascular Forum 2007; 12: 82-86.

14. Hu G, Eriksson J, Barengo NC, et al. Occupational, commuting, and leisure-time physical activity in relation to total and cardiovascular mortality among Finnish subjects with type 2 diabetes. Circulation 2004; 110: 666-673.

15. Hu G, Jousilahti P, Barengo NC, et al. Physical activity, cardiovascular risk factors, and mortality among Finnish adults with diabetes. Diabetes Care 2005; 28: 799-805.

16. Hu G, Lakka TA, Barengo NC, et al. Physical activity in the prevention of type 2 diabetes. Cardiovasc Med 2004; 7: 394-405.

17. Barengo NC, Hu G, Lakka TA, et al. Low physical activity as a predictor for total and cardiovascular disease mortality in middle-aged men and women in Finland. Eur Heart J 2004; 25: 2204-2211.

18. Oguma Y, Shinoda-Tagawa T. Physical activity decreases cardiovascular disease risk in women: review and metaanalysis. Am J Prev Med 2004; 26: 407-418.

19. Rastogi M, Vaz D, Spiegelman KS, et al. Physical activity and risk of coronary heart disease in India. Int $\mathrm{J}$ Epidemiol 2004; 33: 759-767.

20. Yusuf S, Hawker S, Ounpuu S, et al. On behalf of the INTER HEART study investigators: Effect of potentially modifiable risk factors associated with myocardial infarction in 52 countries (the INTER HEART study): case-control study. Lancet 2004; 364: 937-952.

21. Richardson CR, Kriska AM, Lantz PM, et al. Physical activity and mortality across cardiovascular disease risk groups. Med Sci Sports Exerc 2004; 36: 1923-1929.

22. Wendel-Vos GC, Schuit AJ, Feskens EJ, et al. Physical activity and stroke. A meta-analysis of observational data. Int J Epidemiol 2004; 33: 787-798.

23. Lynch BM. Sedentary Behavior and Cancer: A Systematic Review of the Literature and Proposed Biological Mechanisms. Cancer Epidemiol Biomarkers Prev 2010; 19: 2691-2709.

24. Lee IM. Physical activity and cancer prevention - date from epidemiologic studies. Med Sci Sports Exerc 2003; 35: 1823-1827.

25. Thune I, Furberg AS. Physical activity and cancer risk: dose response and cancer, all sites and site-specific. Med Sci Sports Exerc 2001; 33: 530-550.

26. Tuchowska P, Worach-Kardas H, Marcinkowski JT. The most frequent malignant tumors in Poland - the main risk factors and opportunities to optimize preventive measures. Probl Hig Epidemiol 2013; 94: 166-171.

27. Martinez-Gomez D, Guallar-Castillón P, León-Munoz LM, et al. Combined impact of traditional and non-traditional health behaviors on mortality: a national prospective cohort study in Spanish older adults. BMC Med 2013; 22: 47.

28. Pavey TG, Peeters GG, Brown WJ. Sitting-time and 9-year allcause mortality in older women. Br J Sports Med 2012; 1-5.

29. Campbell PT, Patel AV, Newton CC, Jacobs EJ, Gapstur SM. Associations of recreational physical activity and leisure time spent sitting with colorectal cancer survival. J Clin Oncol 2013; 31: 876-885.

30. Warburton DE, Nicol CW, Bredin SS. Health benefits of physical activity: the evidence. CMAJ 2006; 174: 801-809.

\section{Address for correspondence:}

\section{Małgorzata Biskup}

Zakład Rehabilitacji

Świętokrzyskie Centrum Onkologii

3 Artwińskiego St.

25-734 Kielce

Phone: +48606 645865

Email: mbiskup@onet.eu 